\title{
KERJASAMA ANTARA ETNIS MINANGKABAU DAN ETNIS NIAS DALAM KONTEKS SOSIAL BUDAYA DI NAGARI SUNGAI BULUH BARAT
}

\author{
Luthfi Dara Amalia, Maria Montessori, Junaidi Indrawadi \\ Pendidikan Pancasila dan Kewarganegaraan \\ Fakultas Ilmu Sosial Universitas Negeri Padang \\ Luthfiameliaega@gmail.com
}

\begin{abstract}
Religious and ethnic difereces usually make cooperation not work well, howefer this does not occur in the Nagari Sungai Buluh Barat. This article aims to describe the sociocultural cooperation that is intertwined by two ethnic groups and three different religions in the Nagari Sungai Buluh Barat community. This study uses a qualitative approach with descriptive methods. The selection of research informants used a purposive sampling technique. Data is collected through observation, document analysis and interviews. While the data analysis technique are data collection, data reduction, data presentation and input verification conclusions. The result of the study show that socio-cultural cooperation in society is harmoniously interwoven. Collaboration thateexistis social cultural cooperation, religious cooperation, and economic cooperation. Socio-Cultural cooperation consist of mutual cooperation, social events, community organizations and customary attachments. Economic cooperation can be seen from buying and selling and services. Religious cooperation can be seen from the tolerance of religious people in society. As for supporting factors that are carried out, namely mutual respect and respect between etnicities and between religioun. As for the efforts made, nemely fairness of the attitude of the leader and mutual respect.
\end{abstract}

Key words : Cooperation, Ethnic, Socio-Cultural

\begin{abstract}
Abstrak
Perbedaan agama dan etnis biasanya membuat kerjasama tidak berjalan dengan baik, namun hal ini tidak terjadi di Nagari Sungai Buluh Barat. Artikel ini bertujuan untuk menggambarkan kerjasama Sosial-Budaya yang terjalin oleh dua etnis dan tiga agama yang berbeda dalam masyarakat Nagari Sungai Buluh Barat. Penelitian menggunakan pendekatan kualitatif dengan metode deskriptif. Pemilihan informan penelitian menggunakan teknik purposive sampling. Data dikumpulkan melalui observasi, analisis dokumen dan wawancara. Sedangkan teknik analisis data yaitu pengumpulan data, reduksi data, penyajian data dan penarikan kesimpulan varifikasi. Hasil penelitian menunjukkan bahwa kerjasama sosial-budaya yang terjalin di Nagari Sungai Buluh Barat terjalin secara harmonis.. Kerjasama yang terjalin di Nagari Sungai Buluh Barat yaitu kerjasama dari segi sosial-budaya, ekonomi dan agama. Kerjasama dari segi sosial Budaya yaitu Gotong Royong, Acara sosial, organisasi masyarakat dan keterikatan adat. Kerjasama dari segi ekonomi terletak dari segi Jual beli dan jasa. Kerjasama dari segi agama terlihat dari Toleransi Antar Umat beragama di dalam masyarakat. Adapun Faktor pendukung yang
\end{abstract}


dilakukan yaitu saling menghormati dan menghargai antar etnis dan antar agama, adanya toleransi Sosial.Adapun upaya yang dilakukan yaitu adanya keadilan dari Wali Korong terhadap kedua belah Etnis dan Sikap saling menghargai yang terjalin antara Etnis Minangkabau dan Etnis Nias.

\section{Kata kunci: Kerjasama, Etnis, Sosial-Budaya}

\section{PENDAHULUAN}

Agama dan budaya merupakan dua kekuatan yang dapat dijadikan pengikat bahkan pemicu konflik di dalam masalah etnisitas. Oleh sebab itu peranan pemerintah, pemimpin-pemimpin politik, pemimpin pemimpin masyarakat baik formal maupun yang informal sangat menentukan didalam menimbulkan sentimen yang positif maupun yang destruktif dari etnisitas pembangunan masyarakat (Tilaar,2007:16). Kerukunan sebagai fakta hanya terdapat pada umat pemeluk agama yang sama, sebaliknya pembenturan yang terjadi antara antar golongan pemeluk agama yang berlainan tidak sedikit menodai lembaran-lembaran sejarah. Keadaan ini tentu saja menjadi penyebab utama adanya saling tuduh dalam kehidupan bermasyarakat yang disebabkan adanya perbedaan iman, disamping itu faktor suku, ras, dan perbedaan budaya turut memainkan peran yang tidak kecil. (Puspito,2010:169)

Siti Huzaimah (2015) mengatakan bahwa interaksi sosial antara masyarakat pendatang dengan masyarakat pribumi tidak selalu berjalan dengan baik, dalam proses interaksi sosialnya kadang terjadi ketegangan - ketegangan seperti pemberian label kepada salah satu etnis.Selaras dengan Siti, Halikin (2014) mengatakan bahwa perbedaan Etns dan agama tersebut menghasilkan konflik. Baik itu di sebabkan oleh perebutan dominasi sektor perekonomian. Selaras dengan Angga Syaripudin (2014) masyarakat yang heterogen tidak hanya masalah internal agama, bahkan antar umat beragama. Sehingga diskriminasi di sebagian pihak kerap muncul. Dari pendapat ahli dan jurnal dapat disimpulkan bahwa sanya perbedaan agama dan etnis mampu menjadi alasan timbulnya integrasi maupun konflik. Sehingga tidak menutup kemungkinan menyebabkan keadaan disharmoni didalam masyarakat. Sehingga menjalin kerjasama dengan latar belakang, agama, etnis dan kebudayaan yang berbeda tidak lah mudah.

Persamaan penelitian diatas dengan artikel penulis yaitu menganalisis kerjasama sosial di dalam masyarakat yang memiliki agama dan etnis yang berbeda tampa menjelaskan secara rinci. Sedangkan perbedaan dengan skripsi penulis terdapat pada objek kajian yang memfokuskan kepada kerjasama yang terjalin di dalam masayarakat Nagari Sungai Buluh Barat. Penulis mengkategorikan kerjasama menjadi tiga bagian. Pertama, kerjasama masyarakat di bidang Sosial-budaya. Kedua, kerjasama di bidang Ekonomi. Ketiga, kerjasama dibidang agama. Sehingga kerjasama yang dirangkum didalam masyarakat tersebut lebih jelas.

Jika biasanya konflik serta perbedaan paham sering terjadi di dalam masyarakat majemuk namun hal ini tidak ditemukan di Nagari Sungai Buluh Barat 
Kecamatan Batang Anai Kabupaten Padang Pariaman. Masyarakat dihuni oleh orang - orang dengan perbedaan Etnis dan Agama. Pada dasarnya penduduk Nagari Sungai Buluh Barat terdiri dari dua unsur masyarakat yaitu penduduk pribumi dan penduduk pendatang.Walaupun terdiri dari dua etnis dan tiga agama yang berbeda masyarakat Nagari Sungai Buluh Barat hidup berdampingan dan saling bekerjasama satu dengan yang lainnya. Itulah gambaran masyarakat majemuk, dengan perbedaan agama dan etnis di era globalisasi yang menjadi karakteristik dari bangsa Indonesia yang heterogen, sehingga tidak bisa di pungkiri masyarakat majemuk memiliki potensi dan peran yang sangat besar dalam proses integrasi dan pembangunan Nagari Sungai Buluh Barat. Realitas ini didasarkan pada ajaran agama yang mewajibkan umatnya untuk saling mencintai dan hidup rukun berdampingan.

Namun hal itu bisa diatasi, Ester Sumarni (2016) mengatakan bahwa kerjasama di dalam masyarakat yang berbeda Etnis dapat terjalin apabila adanya kerjasama Koalisi. Kerjasama Koalisi adalah penyatuan antar Etnis dalam bentuk musyawarah yang bertujuan untuk mencari solusi. Senada dengan Arif Yulianto (2015) Kerukunan antar Etnis dan agama dapat terjalin disebabkan oleh tingginya toleransi yang dimiliki antar warga dalam masyarakat tersebut. Selaras dengan Ahlan Muzakir (2015) mengatakan bahwa kunci keharmonisan masyarakat adalah dengan adanya toleransi antar agama sehingga menciptakan rasa aman bagi agama minoritas. Namun musyawarah yang dilakukan tidak selalu efektif dalam memecahkan suatu permasalahan. Kita butuh tidakan pencegahan sehingga masalah tidak timbul. Sehingga keharmonisan tetap terjaga di dalam masyarakat.

Solusi yang penulis tawarkan disini adalah bagaimana cara melakukan pencegahan sehingga konflik bisa diminimalisir di dalam masyarakat. Salah satunya adalah pola kepemimpinan Wali Nagari dan Wali Korong dalam bersikap di dalam masyarakat. Sikap pemimpin terhadap etnis satu dengan etnis yang lain hendaklah bersikap adil. Baik itu dalam rapat, pembagian bantuan bahkan sikap. Misalnya ketika adanya rapat ataupun musyawarah, sebaiknya pemimpin memberikan kesempatan berbicara antar etnis satu dengan etnis lainnya. Hal ini membuat etnis minoritas merasa dihargai dan merasa nyaman untuk tinggal di wilayah tersebut. Sehingga konflik dapat dihindari antar etnis satu dengan etnis lainnya.

Hal ini menjadi alasan yang menarik minat penulis untuk melihat hubungan Masyarakat yang berbeda Etnis dan Agama tersebut dalam konteks Kerjasama sosial-budaya nya di kawasan pemukiman dengan mempertimbangan Nagari Sungai Buluh Barat sebagai daerah yang diamati. Pertimbangan ini berkaitan dengan banyak hal antara lain posisinya sebagai model kerukunan masyarakat multikultural. Selain itu jika dikaitkan khusus pada hubungan etnis Minangkabau dan Etnis Nias yang sejatinya telah berlangsung sejak lama di Nagari Sungai Buluh Barat Serta peneliti merasa perlu meneliti bagaimana interaksi sosial yang terjadi antara penduduk lokal atau pribumi Etnis Minang dengan pendatang Etnis 
49 |Kerjasama antara etnis...

Nias.Penelitian ini juga dirasa penting dilakukan karena terdapat keberagaman agama serta budaya di desa ini serta memberikan sumbangsih atau pemikiran pada lingkungan akademik dalam hal mengajarkan mengenai pendidikan multikultural yang sedang gencar-gencarnya dibicarakan pada dunia pendidikan Indonesia

\section{Metodologi Penelitian}

Penelitian ini menggunakan metode kualitatif yang bertujuan untuk menggambarkan bentuk kerjasama sosial-budaya yang terjalin di Nagari Sungai Buluh BaratPemilihan informan penelitian menggunakan teknik purposif (purposive sampling). Jenis data yang digunakan dalam penelitian ini adalah data Primer dan data sekunder. Pengumpulan melalui observasi, analisis dokumen, dan wawancara. Untuk menguji keabsahan data dalam penelitian ini yaitu triangulasi teknik. Teknik analisa data yaitu pengumpulan data, reduksi data, penyajian data dan penarinkan kesimpulan varifikasi.

\section{Hasil Dan Pembahasan}

1. Kerjasama yang terjadi antara Etnis Minangkabau dan Etnis Nias dalam sosial - budaya, agama dan ekonomi di Nagari Sungai Buluh Barat Kecamatan Batang Anai

Berdasarkan hasil observasi yang peneliti lakukan, tentang mengamati secara umum lingkungan Nagari Sungai Buluh Barat Kecamatan Batang Anai Kabupaten Padang Pariaman yang terlihat adalah dalam kesehariannya masyarakat sudah berinteraksi dengan baik dan terlihat harmonis. Semua masyarakat baik Etnis Minangkabau ataupun Etnis Nias saling berkerjasama dengan baik. mereka melakukan kontak komunikasi saat berpapasan di jalan atau saling menyapa. Hal tersebut terjadi karena lamanya kedua etnis ini hidup secara berdamipingan dan saling membutuhkan satu sama lain.berdasarkan masalah maka kerangka konseptual dalam bagan sbb: 


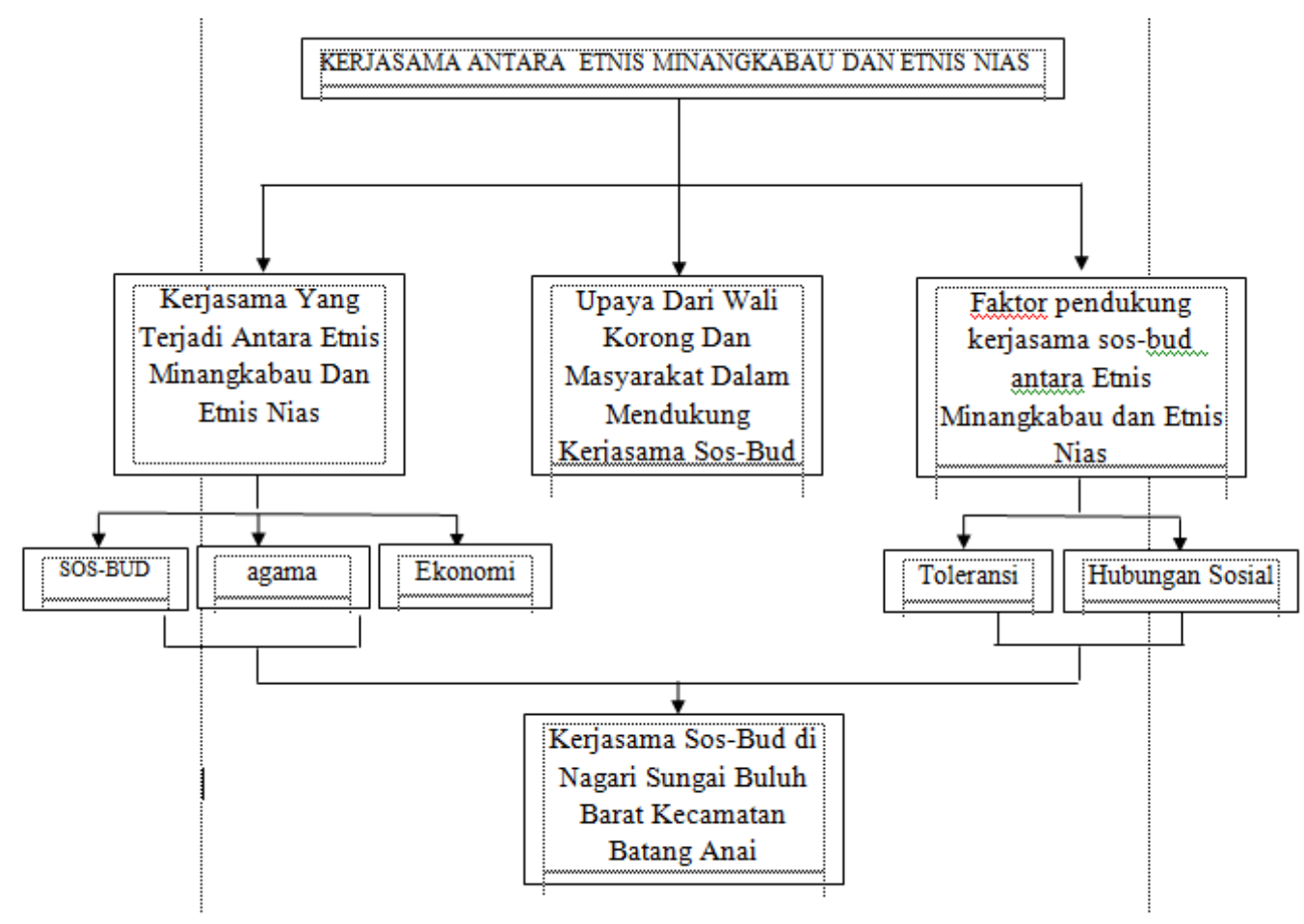

Interaksi sosial merupakan hubungan hubungan sosial yang dinamis yang menyangkut hubungan antara orang perorangan, antara kelompok kelompok manusia (Soerjono, 2013 : 55).Manusia adalah makhluk Tuhan yang unik satu sama lain. Perilaku maupun tindakan manusia se unik apapun tidak terlepas dari pengaruh lingkungan sosial nya. Sejak manusia lahir kedunia manusia melakukan interaksi dengan sesamanya. Interaksi sosial juga erat kaitannya dengan naluri manusia untuk selalu hidup berdampingan. Serta ingin bersatu dengan lingkungan sosialnya. Interaksi sosial merupakan bentuk pelaksanaan kedudukan manusia sebagai makhluk sosial. Dengan demikian interaksi sosial yang ada di Nagari Sungai Buluh Barat sudah berjalan dengan baik dan terlihat harmonis walaupun dengan kemajemukan etnis yang ada. Hal ini terlihat dari terjalinnya kerjasama yang baik antar masyarakat multi etnis.

Berdasarkan hasil wawancara dengan narasumber Kerjasama yang dilakukan antara Etnis Minangkabau dan Etnis Nias di Nagari Sungai Buluh Barat terdiri atas kerjasama sosial-budaya, ekonomi dan agama. Kerjasama ini diwujudkan dalam kehidupan sehari hari masyarakat disini. Kerjasama yang dilakukan dalam segi sosial-budaya terdiri dari kerjasama dalam kegiatan sosial, adat istiadat, kebudayaan dan tradisi dan bahasa. Kerjasama dalam kegiatan sosial terdiri atas gotong royong, organisasi masyarakat berupa PKK, aktifitas Posyandu. sedangkan dalam adat istiadat karena adanya "adaik dipacik, limbago dituang" sehingga membuat adat Etnis Nias sudah bercampur dengan Adat Minang. Hal ini terlihat ketika pesta 
pernikahan (Acara Baralek)Etnis Nias mereka memakai dua pakainan adat, pertama pakaian adat Nias dan yang kedua pakaian adat Etnis Minang.
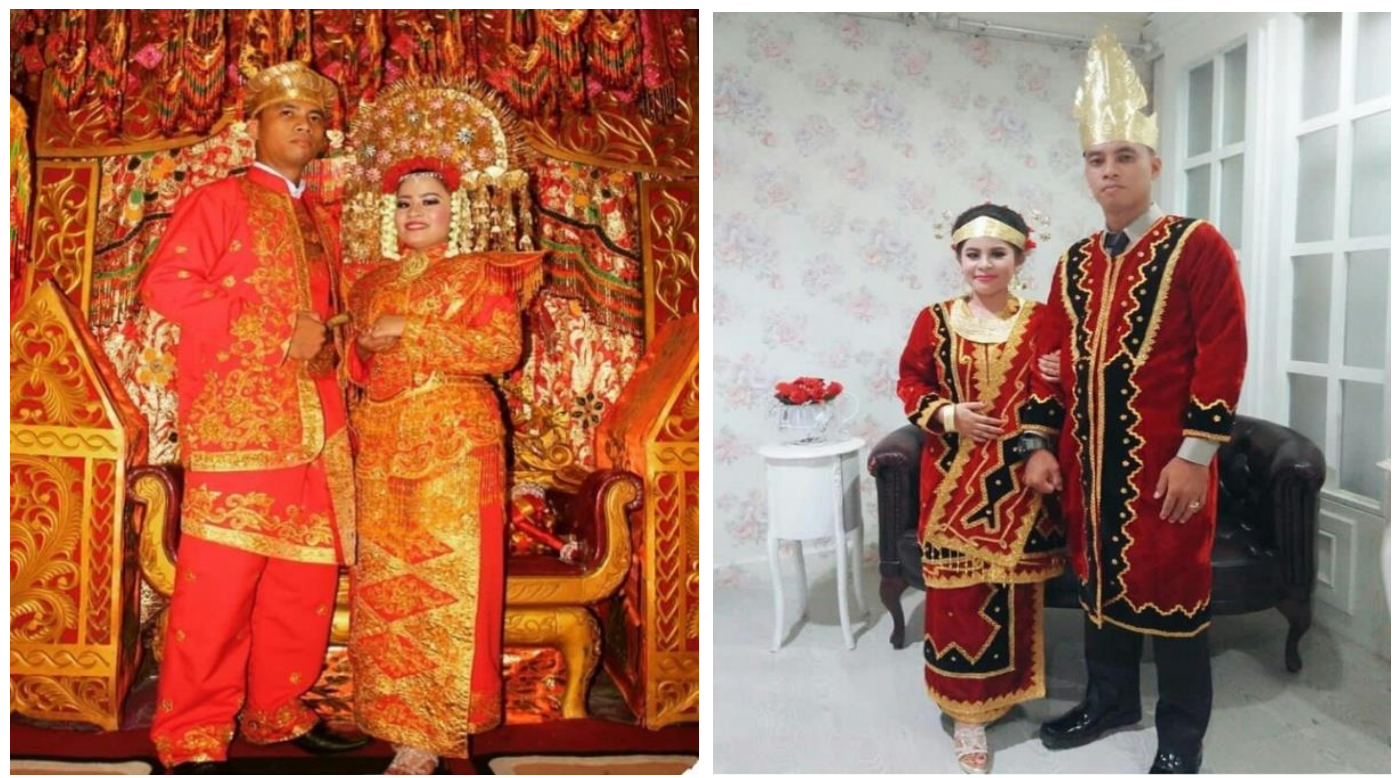

Gambar 1..Pernikahan Etnis Nias memakai pakaian adat Minang dan Nias

Komunikasi yang terjalin di Nagari Sungai Buluh Barat ini terjalin lancar. Pada umumnya masyarakat mengguunakan bahasa Minang dalam berkomunikasi seharihari. Walaupun begitu tidak menimbulkan masalah bagi Etnis Nias. Bahasa Minang Sudah dikuasai oleh Etnis Nias sehingga komunikasi dengan Etnis Minangkabau tidak terjadi kesalah pahaman. Kemampuan menggunakan bahasa Minang adalah salah satu cara beradaptasi Etnis Nias di dalam masyarakat nagari Sungai Buluh Barat.Kerjasama dari segi ekonomi terdiri dari kerjasama dalam menjalankan usaha dan penyediaan tempat berdagang.. Kerjasama dari segi jual beli terjadi di Depan Gereja 1 dan 2. Pedagang memanfaatkan hari Minggu ketika Etnis Nias melakukan ibadah dan ketika hari Natal. Etnis Minangkabau biasanya berdagang makanan,minuman sampai mainan. Hal ini di sambut baik oleh Etnis Nias yang pada dasarnya membutuhkan hal itu seusai ibadah yang mereka lakukan

Kerjasama dari segi agama merupakan bentuk toleransi beragama. Toleransi dalam pergaulan hidup antar umat beragama, yang didasarkan kepada setiap agama menjadi tanggung jawab pemeluk agama itu sendiri dan mempunyai bentuk ibadat (ritual) dengan sistem dan cara tersendiri yang ditaklifkan (dibebankan) serta menjadi tanggung jawab orang yang pemeluknya atas dasar itu, maka toleransi dalam pergaulan hidup antar umat beragama bukanlah toleransi dalam masalahmasalah keagamaan, melainkan perwujudan sikap keberagamaan pemeluk suatu agama dalam pergaulan hidup antara orang yang tidak seagama, dalam masalahmasalah kemasyarakatan atau kemaslahatan umum (Al Munawar, 2003:14)Bentuk toleransi beragama di Nagari Sungai Buluh Barat ini tampak dari sikap masyarakat yang saling menghormati dan menghargai satu sama lain. Toleransi juga tampak dari sikap dari Etnis Nias yang meniggakan salah satu adat nya yanidalam meminum minuman keras karena menimbang Etnis Minangkau yang dominan Islam. 


\section{Faktor pendukung terjadinya kerjasama sosial-budaya di Nagari Sungai Buluh Barat}

Berdasarkan deskripsi data yang diperoleh dilapangan terdapat indikasi adanya beberapa faktor yang mendukung terwujudnya proses dan kondisi yang harmonis dari kerjasama antara Etnis Minangkabau dan Ernis Nias. Faktor pendukung antara lain adanya toleransi kedua belah pihak kelompok Etnis dan Pola kepemimpinann Wali Nagari dan Wali Korong. Adanya toleransi yang cukup tinggi dari kedua belah pihak Etnis ikut mendorong kesadaran tubuhnya kesadaran bahwa adanya perbedaan bukanlah halangan untuk bersatu. Perbedaan - perbedaan tidak mempengaruhi masyarakat Nagari Sungai Buluh Barat dalam melakukan kerjasama. Faktor pendorong kerjasama di Nagari Sungai Buluh Barat ada dua. Pertama adanaya toleransi dari kedua etnis dan adanya hubungan sosial yang baik di dalam masyarakat nagari Sungai Buluh Barat.

Toleransi merupakan suatu sikap atau perilaku manusia yang mengikuti aturan, dimana seseorang dapat menghargai menghormati terhadap perilaku orang lain. Istilah toleransi dalam dalam konteks sosial budaya dan agama berarti sikap dan perbuatan yang melarang adanya diskriminasi terhadap kelompok atau golongan yang berbeda dalam suatu masyarakat seperti toleransi dalam beragama, dimana kelompok agama yang mayoritas dalam suatu masyarakat, memberikan tempat bagi kelompok agama lain untuk hidup dilingkungannya. (Abu bakar, 2015:1). Ahlan muzakir (2015) mengatakan bahwa kunci keharmonisan masyarakat adalah dengan adanya toleransi antar agama sehingga menciptakan rasa aman bagi agama minoritas.Toleransi yang terjalin di Nagari Sungai Buluh Barat ini berupa mematikan hal bising ketika adzan berkumandang oleh Etnis Nias. Hal serupa juga dilakukan etnis Minang yang menjaga keadaan dan kondisi agar kegiatan keagamaan dari Etnis Nias tidak terganggu.

\section{Upaya yang dilakukan oleh Wali Nagari dan Wali Korong dalam kerjasama Sosial - Budaya di Nagari Sungai Buluh Barat.}

Pola kepemimpinan Wali Nagari dan Wali Korong juga berperan penting dalam menyatukan kedua Etnis, antara lain dengan memberikan perlakuan yang sama kepada kedua kelompok dalam pemberian kesempatan mengemukakan pendapat dalam rapat - rapat, aktifitas aktifitas sosial, seperti organisasi masyarakat posyandu dan kegiatan kegiatan lainnya. masalah dalam kerjasama adalah bagaimana mengembangkan pola interaksi yang positif yang lebih lekat. Meningkatkan integrasi yang sudah cukup baik menjadi kesatuan yang kohesi dan mantap. Seperti dengan adanya pembinaan kesadaran akan integrasi dan partisipasi.. maka pemecahannya harus dilakukan dengan cara musyawarah sehingga muncul kesadaran untuk bekerjasama. Hal ini juga dikatakan Esti Sumarni (2016) bahwa kerjasama didalam masyarakat yang berbeda etnis dapat 
terjalin apabila adanya kerjasama koalisi. Kerjasama koalisi adalah penyatuan antar etnis dalam bentuk musyawarah untuk mencari solusi.

Perlakuan yang sama bagi masing masing Etnis Sehingga tidak ada yang merasa di diskriminasi. Miasalnya saja memberikan kesempatan bebrbicara kepada Etnis Nias ketika melakukan rapat. Memberikan dana bantuan secara adil oleh kedua belah Etnis. Tidak membeda bedakan antara Etnis Minangkabau dengan Etnis Nias. Saling menghormati an tennggang rasa, sehingga keharmonisan tetap terjaga.

\section{Kesimpulan Dan Saran}

\section{A. Kesimpulan}

Berdasarkan hasil penelitian dan pembahasan yang telah dilakukan secara umum maka dapat disimpulkan bahwa kerjasama Sosial-Budaya antara Etnis Minangkabau dengan Etnis Nias di Nagari Sungai Buluh Barat terbilang Harmonis. Dimana masyarakat Etnis Minang Dan Etnis Nias saling Toleransi serta menghargai satu sama lain. Ditambah Etnis Nias berupaya untuk bisa diterima dan berinteraksi dengan Etnis Minangkabau sehingga menghasilkan kerjasama yang terjalin baik. Kerjasama antara Etnis Minangkabau dengan Etnis Nias terdiri atas kerjasama dari segi sosial-budaya, ekonomi dan agama. Kerjasama dari segi sosial-budaya terlihat dari kerjasama dalam kegiatan sosial,adat istiadat,kebudayaan dan tradisi, dan bahasa. Kerjasama dari segi ekonomi terlihat dari kerjasama dalam menjalankan usaha dan penyediaan tempat berdagang. Kerjasama dari segi agama terdiri atas saling menghormati dalam acara keagamaan dan menghargai satu sama lain.Faktor pendorong kerjasama di wilayah ini adalah adanya toleransi dari kedua etnis dan hubungan sosial yang baik antar etnis. Upaya yang dilakukan oleh Wali Nagari dan Wali Korong adalah dalam pola kepemimpinannya. Dimana pemimpin mampu berlaku adil antar Etnis satu dengan Etnis lainnya. Sehingga Etnis minoritas merasa dihargai dan hidup dengan nyaman di Nagri Sungai Buluh Barat.

Hasil penelitian ini diharapkan dapat memberikan kontribusi bagi ilmu pengetahuan khususnya kajian PPKN dalam pendidikan multikultural dalam menjelaskan kerukunan masyarakat mulikultural di Indonesia, khususnya agama Islam dan Kristen serta Katolik di Indonesia. Serta dapat menambah wawasan dan informasi pada penelitian selanjutnya yang tertarik dengan kajian kajian tentang hubungan sosial yang terjadi di masyarakat multikultural sebagai salah satu bentuk masyarakat Indonesia yang menganut "bhineka Tunggal Ika". Hasil penelitian ini diharapkan menambah wawasan pengetahuan bagi pembaca dan mahasiwa tentang dinamika kerjasama sosial masyarakat Nagari Sungai Buluh Barat. Hasil dari penelitian ini dapat memberikan pedoman bagi warga di Nagari Sungai Buluh Barat dalam menjaga hubungan antar umat beragama untuk menghindari konflik antara anggota masyarakat khususnya yang berbeda agama.Hasil penelitian ini diharapkan dapat memberikan kontribusi juga bagi ilmu pengetahuan khususnya kajian Sosiologi dalam mengkaji kerjasama yang terjadi di dalam masyarkaat yang memiliki perbedaan Etnis Agama Budaya, bahasa dan lain lain. Serta dapat dijadikan acuan apabila akan dilakukan penelitian lanjutan. 


\section{B. Saran}

Dari hasil penelitian di bab sebelumnya, penulis memberikan saran sebagai berikut :

1. Kepada Etnis Minangkabau dan Etnis Nias untuk selalu bisa menjaga dan menghargai kegiatan yang dilakukan oleh kedua Etnis untuk kebaikan bersama di Nagari Sungai Buluh Barat.

2. Kepada seluruh masyarakat Nagari Sungai Buluh Barat untuk mempertahankan keharmonisannya di dalam hidup berdampingan meskipun berbeda adat istiadat dan agama.

3. Untuk seluruh masyarakat Nagari Sungai Buluh Barat harus kritis didalam suatu permasalahan yang terjadi karena banyaknya provokator yang bisa menyebabkan hancurnya keharmonisan yang selama ini yang terjadi antara masyarakat Etnis Minangkabau dengan Etnis Nias.

\section{Daftar Pustaka}

Ahlan Muzakir.2015. Masyarakat Islam dan Hindu di Dusun Sumberwatu Desa Sambirejo Kecamatan Prambanan dalam mengembangkan Kerukunan Agama.Skripsi.Fakultas Ushuluddin dan Pemikir Islam.Universitas Islam Negeri Sunan Kalijaga Yogyakarta

Arif Yulianto.2015.Pengaruh Toleransi Antar Umat beragama Terhadap perkembangan Islam di dusun Margosari di Desa Ngadirejo Kecamatan Ampel.Skripsi.Fakultas Tarbiyahdan Ilmu Keguruan.Institut agama Islam negeri Salatiga.

Abu Bakar.2015.TOLERANSI: Media Komunikasi Umat beragama, Vol 7, No.2 JuliDesember 2015

Al Munawar, Said Agil Husin. 2003. Fikih Hubungan Antar Umat Beragama. Jakarta: Ciputat Pess

Ester Sumarni.2016. Interaksi sosial kerjasama masyarakat multi etnis (Dayak, Madura Melayu) di DesaKenaman Kecamatan Sekayan. Jurnal. FKIP Untan Pontianak.

Halikin.2014. Analisis Pola Interaksi Masyarakat Pendatang Terhadap Masyarakat Lokal Di Sumbawa Barat Studi di Kecamatan Maluk, Sumbawa Barat, NTB.UIN Syarif Hidayatullah.Jakarta 
55 |Kerjasama antara etnis...

H.A.RTilaar.2007.Mengindonesiakan etnisitas dan identitas bangsa Indonesia, Jakarta :Rineka Cipta.

Puspito, Hendro 2016. Sosiologi Agama. Yogyakarta:Kanisius.

Siti Huzaimah.2015.Interaksi Sosial Transmigran Suku Jawa dengan Pribumi Putra, Lampung.Skripsi.Fakultas Ushuluddin dan Pemikir Islam.Universitas Islam Negeri Sunan Kalijaga Yogyakarta.

Soerjono Soekamto 2013. Sosiologi suatu pengantar .Jakarta Rajawali Pers 